\title{
Networked trafficking: reflections on technology and the anti-trafficking movement
}

\author{
Mitali Thakor $\cdot$ danah boyd
}

Published online: 24 April 2013

(C) The Author(s) 2013. This article is published with open access at Springerlink.com

\begin{abstract}
In this essay, we offer field notes from our ongoing ethnographic research on sex trafficking in the United States. Recent efforts to regulate websites such as Craigslist and Backpage have illuminated activist concerns regarding the role of networked technologies in the trafficking of persons and images for the purposes of sexual exploitation. We frame our understanding of trafficking and technology through a network studies approach, by describing anti-trafficking as a counter-network to the sex trafficking it seeks to address. Drawing from the work of Annelise Riles and other scholars of feminist science and technology studies, we read the anti-trafficking network through the production of expert knowledge and the crafting of anti-trafficking techniques. By exploring anti-trafficking activists' understandings of technology, we situate the activities of anti-trafficking experts and law enforcement as efforts toward network stabilization.
\end{abstract}

Keywords Sex trafficking $\cdot$ Internet studies $\cdot$ Network studies $\cdot$ Feminist STS

\section{Introduction}

"There's kind of a cynical argument to make that if-and this is an if-the overall sales of sex of minors on the Internet did not decrease with the closing

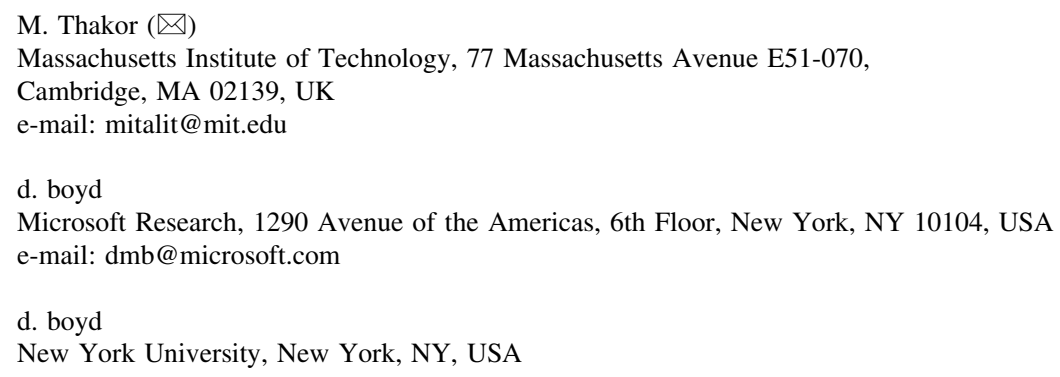


down of Craigslist, did we, in fact, just make [anti-trafficking] communities be able to feel better about themselves? ... I heard someone say that Craigslist was like the Wal-Mart for selling things on the Internet... And if the average person can now get Craigslist and say 'No one's being sold on Craigslist therefore no one's being sold,' did we, in fact, do a disservice to working on this issue because we've now told people that it's taken care of, if in reality it's not? Because look, you know, in America we have this very long history of sort of moving things we don't want to see into places where we don't have to see it and therefore it doesn't exist. We do it with our poor people. We do it with ugly parts of town; we make sure there are interstates that go around it and so people with means and power can live their lives and days without seeing it. And so, I guess my fear about restrictions on technology or closing down certain websites is 'Are we just building our freeway around the issue and not actually tackling the issue?",.

Director of a human trafficking legal clinic.

On September 4, 2010, Craigslist removed its "Adult Services" and replaced the link to the section with one word: "censored" (Saletan 2010). After years of vilifying the site, anti-human trafficking advocates celebrated this decision as a victory in the fight to end sexual slavery and the commercial sexual exploitation of children (Albanesius 2010; CNN 2010; Gruenwald 2010). On September 7, 2010, four national and international anti-trafficking organizations, Courtney's House, FAIR Fund, Polaris Project, and The Rebecca Project for Human Rights released a statement lauding the decision, stating the closure "sends a clear signal to sexual predators that it will not stand for them using the site to sexually enslave children and young women" (Gruenwald 2010).

In the months leading up to September 4, 2010, the battle over whether or not to shut down Craigslist became deeply political and acutely polarizing. On both sides of the debate, research was employed to justify means and defend positions. For example, the Women's Funding Network, one of the key anti-trafficking organizations behind the campaign to shut down Craigslist, commissioned research from The Schapiro Group, which suggested that the commercial sexual exploitation of children in three states was on the rise (Schapiro Group 2011). David Finkelhorthe director of the Crimes Against Children Research Center-criticized the methodology and findings (Pinto 2011). Yet, because his critique was published in The Village Voice, which owns Backpage-a classified service similar to Craigslist-many anti-trafficking organizations ignored his critique. To provide data showing that shutting down Craigslist was effective, the AIM Group released data in 2012 indicating that prostitution ad revenue (see footnote 1) had declined and had shifted to other sites (The AIM Group 2012). Although these data made no distinction between sex work and sex trafficking, the data were celebrated as proof that anti-trafficking crusades against websites were effective.

Actors framed their positions on Craigslist's "Adult Services" relative to dominant American discourse on human trafficking and child sexual exploitation as well as older and still relevant debates on the legality of sex work. In the United States, the concept of human trafficking has migrated from specialized sex abuse 
and refugee shelters to the everyday lexicon of politicians, churches, and international aid organizations. Anthropological and sociological analyses of human trafficking explore the concept through tracing its etymology (Ditmore 2005; Doezema 2010; Musto 2009), understanding trafficking anthropologically in social and cultural contexts (Kempadoo and Doezema 1998), and framing trafficking as an economic outcome of globalization and neoliberalism (Anderson and O'Connell Davidson 2003; Enloe 1990; Outshoorn 2004). In recent years, scholarship has also emerged to critique anti-trafficking-as an activist "movement"-in terms of its moral, political, and financial composition (Andrijasevic 2007; Doezema 2010; Soderlund 2005; Weitzer 2007).

Financial commitments have come under scrutiny: anti-trafficking organizations criticized Craigslist and Backpage for profiting off of the commercial sexual exploitation of children (Boothroyd 2012; Saar 2012; Sarnoff 2012). ${ }^{1}$ Other critiques have emerged regarding corporate commitments toward anti-trafficking, primarily targeted at Google for its dual role as a funder of anti-trafficking movements and for simultaneously profiting from proceeds of adult services sites (National Association of Human Trafficking Advocates 2012). Meanwhile, sex workers accused anti-trafficking advocates of capitalizing on donations meant to combat exploitation of children to instead (or also) target sex workers for moral reasons. Social critiques of "the new abolitionists" suggest that the anti-trafficking movement is a device for policing sex work in general (Augustin 2007; Bernstein 2007; Chapkis 1997; Desyllas 2007; Doezema 1998, 2010; Kempadoo and Doezema 1998). Many of the debates in academic and activist circles stem from disagreements over who is trafficked and what policies, tools, and actions enable trafficking.

Classifieds websites have become new battleground spaces upon which longstanding disagreements about sex work, human trafficking, and the sexual exploitation of youth are enacted. The affordances of Internet technologies - and the for-profit nature of the companies creating the technologies-became rhetorical weapons to galvanize support. For example, Andrea Powell of the anti-trafficking group the FAIR Fund called Craigslist "the Wal-Mart of online sex trafficking" (Gerhart 2010) while numerous anti-trafficking advocates argued that ordering sex with a minor online is "as easy as ordering a pizza" (Hinman and Patria 2012). Such analogies imply that technology companies choose to sell children as a product while technologies themselves make exploitation easier and more accessible.

Our research interest is stimulated by the ways anti-trafficking advocates are positioning themselves around classifieds sites and social media technologies. In parsing through these multivalent discourses, we seek to analyze how antitrafficking advocates understand the role of technology in the commercial sexual exploitation of children and simultaneously define "anti-trafficking" and its parameters for their agencies and their constituencies. In doing so, we began to

\footnotetext{
${ }^{1}$ It is important to note that Craigslist did not originally charge for "adult services ads." In April 2009, state attorneys general led by Connecticut Attorney General Richard Blumenthal encouraged Craigslist to charge for ads to ensure a credit card record of potential exploiters of minors through the site (Connecticut Attorney General's Office 2009). At the time, it was believed that charging for ads would decrease the availability of exploitative ones.
} 
recognize that, by altering the flow of information and reworking what is and is not visible, technology is reconfiguring many of the networks that underpin many aspects of human trafficking generally and commercial sexual exploitation of children specifically. Discourses around technological determinism, descriptions of what constitutes "technology" (cell phones, websites, peer-to-peer networks, etc.), and the positive or negative valences ascribed to various technologies became central questions for us. For example, the same communication tools that enable illicit exchanges are also employed by anti-trafficking advocates to coordinate and spread their messages.

Informed by feminist science and technology studies (STS), we locate our analysis of anti-trafficking discourses on technology in terms of networks, power, and expertise. In an effort to understand the disruptive role of technology in the antitrafficking movement, we draw from STS to position anti-trafficking as a "counternetwork" to the trafficking that it seeks to address. Drawing from Castells, we suggest that anti-trafficking actors shape policy as affective responses to information, while simultaneously maintaining "survivability" or ontological stasis by operating within their node of the network (2009: 23). By viewing trafficking and anti-trafficking as networks, we highlight the flows of power-financial and informational-that enable certain political agendas. We also highlight the importance of "relationality" (Strathern 1991; Riles 2002) in the articulation of power, as we track how actors negotiate the strategic, relational, and productive character of their role in such networks.

Based on our preliminary research, we suggest that the primary issue here is about stabilization of networks: How has technology, broadly construed, disrupted the trafficking of persons in the US? How has technology altered the power dynamics in the ecosystem surrounding trafficking? How has the anti-trafficking network responded in turn, through the mobilization of certain actors, resources, and agendas? Drawing on our initial fieldwork, this essay offers some reflections on how trafficking operates as a networked phenomenon, the ways in which technology destabilizes the phenomenon, and the ways that anti-trafficking advocates respond to that destabilization.

\section{Methodology}

In order to understand how different constituent groups understand the role of technology in human trafficking, we began by attending anti-trafficking meetings, meeting with anti-trafficking advocates and law enforcement officers, and speaking with political aides working on the issue. We joined anti-trafficking working groups, hosted events to engage anti-trafficking advocates, and met with technologists and agencies looking to design and implement technologically mediated solutions.

The bulk of the data for this essay comes from semi-structured phone interviews we conducted from September 2011 through April 2012 with 12 advocates representing different US-based anti-trafficking organizations. Following the anthropological notion of "studying up" (Nader 1972) as applied to studies of technoscience (Forsythe 1999), as well as STS studies of activism and expertise 
(Epstein 2000; Collins and Evans 2002), we focused on anti-trafficking advocates who positioned themselves as experts and policy influencers on sex trafficking and/ or sexual exploitation of children. Interviews were conducted by phone and lasted from one to $2 \mathrm{~h}$ in length. We attempted to maximize geographic diversity within the United States in this round of interviews: we spoke with one advocate from Massachusetts, two from New York, one from Washington, DC, three from Georgia, one from Michigan, one from Texas, and three from California. All but one of those interviewed were female.

Advocates were told that this was preliminary research into the relationship between technology and human trafficking. Many expressed that they were not technology experts, and we informed them that we wanted their expertise as antitrafficking advocates. Advocates were told that scholars from Microsoft Research were conducting this study in collaboration with an anthropology $\mathrm{PhD}$ student from MIT (who conducted the interviews). All interviews were recorded and advocates were told that their identities would remain confidential.

We began interviews by asking informants to describe their work with their organizations and reflect upon their credentials, interest in, and general role within the current state of human trafficking issues in their region. Given that there exists a broad spectrum of attitudes and definitions of trafficking (Musto 2009), we followed by asking informants to define trafficking as pertinent to their organization. We then asked informants to describe their understanding of how technology is implicated with trafficking, offer specific cases and examples from their regions, and reflect upon recent "crack-downs" on websites with online sex service components, such as Craigslist and Backpage. Finally, we followed by asking informants to describe existing prevention methods and offer ideas for technological interventions to diminish trafficking and exploitation.

\section{Locating sex trafficking}

Sex trafficking resists easy definition and is alive with frictions between legal codes, local morals, and the competing discourses of law enforcement, international governing bodies, sex workers' rights groups, and faith-based, self-described "abolition" agencies. In the United States, the federal Trafficking Victims Protection Act (TVPA), authorized in 2000 and reauthorized in 2008, sets a national definition for "human trafficking." According to the TVPA, "severe forms of trafficking in persons" includes "sex trafficking in which a commercial sex act is induced by force, fraud, or coercion, or in which the person induced to perform such act has not attained 18 years of age;" or "the recruitment, harboring, transportation, provision, or obtaining of a person for labor or services, through the use of force, fraud, or coercion for the purpose of subjection to involuntary servitude, peonage, debt bondage, or slavery. 2 " The TVPA sets the federal standard, but state and local jurisdictions often have additional anti-trafficking statutes that define sex trafficking

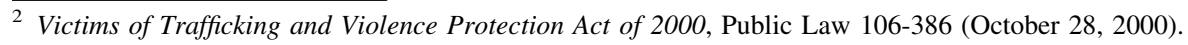


differently, and this tension between local and federal definitions was reflected in the responses of our interviewees' asked to provide a definition of trafficking.

A social worker at a victim protection services organization offered several levels of definition by way of explanation. She stated on behalf of her organization, "we use just one definition, the federal definition." She explained that federal law "provides stronger sentencing guidelines than [New York] state" and as a prosecutor, the strength of the rubric for prosecution is prioritized: "if you're going to prosecute, I think you want the strongest penalties for the traffickers if they are found guilty." She emphasized that "trafficking is an identification issue," particularly, in classifying labor trafficking and sex trafficking cases. For her legal-centric organization, client protection and successful prosecution are priorities, and the definition of trafficking operationalized is both unimportant and yet hugely consequential as it sets legal precedents. She explained that "we the organization feel strongly that force, fraud, and coercion have to be part of the definition for it to be trafficking versus prostitution or sex work," adding that "that's what our funders require."

The director of a human trafficking legal clinic echoed this sentiment of federal versus state-level prosecution. She stated, "When you look at sex trafficking, because prosecution is an area of law that's reserved to the states, which means the federal law's out there, but most law enforcement is state and local...they [prosecutors] are still going by what their state law says... Federal law says what it says about 'under 18.' Our state law says you can be arrested for prostitution 16 and up. So, it depends on what agent encounters the person how they're going to be treated. That means every single one of the underage sex trafficking cases we have, we take to the feds. We never take them to the state and locals." For legal actors working with police and federal law enforcement, a delicate negotiation between local statutes and legal efficacy is necessary.

Other advocates focus more on an experiential definition. For example, a sex work advocate working to combat exploitative sex work-defined trafficked persons as those who are moved "at some point against their will, with coercion involved" and have "no freedom" in their place of work. She then ceded that her organization was committed to being "the low-threshold program" focused on employing a wide-reaching harm-reduction perspective; "For us it's not how you got to where you are...but we tend to recognize and see when people are trafficked and forced into their work."

While sex work advocates often distinguish between consensual sex work and coerced or exploitative sex work, other advocates see all forms of sex work as sexual enslavement. An advocate with a national anti-slavery organization described all trafficking and sex work as "modern-day slavery." She framed her organization's commitment as one of abolitionism.

The tensions described by our informants are reflected in language use and etymologies that researchers have consistently found to be present in anti-trafficking circles (Musto 2009). Soderlund (2005) and Doezema (2010) document a rise in American and international "abolitionist" organizations that comprise professionalized "freedom fighters," whose motivations lie between a Christian faith-based rhetoric of saving (female) victims and a radical feminist politic that reads all 
prostitution as systemic sexual coercion (Dworkin 1993; MacKinnon 1993, 2004). Over the past twelve years, the US government has also made sweeping efforts to address and criminalize trafficking activity. The effort was first launched on a national scale under George H. W. Bush's administration, which was instrumental in the passing of TVPA and influencing the US' international stance toward trafficking. President Obama has upheld Bush-era policies on trafficking, arguing that trafficking "must be called by its true name-modern slavery" in his September 2012 speech at the Clinton Global Initiative.

The rights-based discourse of abolition-motivated anti-trafficking reduces systemic power inequalities to the level of the individual, to the psychiatric conditions of coercion or trauma of the trafficker and the trafficked person, respectively. The goal of an abolitionist movement is individual emancipation, inspired by a notion of agency and possessive individualism that emerges from a long lineage of Western Enlightenment scholarship focused on the freedom of the individual self, a position whose ethnocentrism has been critiqued by postcolonial feminist theorists (Charlesworth et al. 1991; Mahmood 2004; Riles 2002). This individualistic discourse is amplified in American anti-trafficking, where a simplistic dialectic of freedom/slavery pervades activist rhetoric in the use of phrases such as "the modern-day slavery," the "new abolition movement," and "breaking the chains of slavery."

Bernstein calls the anti-trafficking movement focused on abolitionism an example of "carceral feminism" meets "militarized humanitarianism," where neoliberal market logics dominate the discourse (2010: 47). For example, Siddharth Kara is an investment banker turned anti-trafficking researcher who has gained distinction for his economic modeling of trafficking in order to suggest businessdriven solutions to the issue (Kara 2009).

Anti-trafficking is a slogan and a professional field as well as an emancipatory politic, one which veers toward the defense of personal rights and freedom via othering salvation discourse. In global anti-trafficking networks, the othering effects of rights-based discourse means differential treatment of trafficked persons inside and outside European American countries: as Riles writes, "Rights—as project and representation-index the outside, the other-others' interest in rights [and] violations of rights elsewhere" (2002: 304). The "euphoria sometimes prompted by the vocabulary of human rights may occasionally distract us" (Charlesworth et al. 1991) from the deeply diffused and overwhelmingly collective, not individualistic, nature of injustice and inequality. The networked constellation of actors involved in the anti-trafficking movement are simultaneously brought together by a shared commitment to addressing a form of abuse and positioned in opposition to one another based on how they construct that abuse and what strategies and tactics they believe should define the agenda.

\section{Networks and counter-networks}

While definitional issues might not appear significant to trafficking advocacy, the definition of trafficking used by an anti-trafficker not only signals the ontological 
commitments of its speaker, it also indicates the pathways of anti-trafficking that this actor will take as information flows through their networks. Over the past 20 years, anti-trafficking has emerged as a legal concept, an activist movement, and a political position held aloft by its antithesis, trafficking. Annelise Riles argues that the "constellation" of academic and activist debates, people, ideas, and institutions associated with an issue at a specific moment serve to simultaneously reify the issue and produce professionalized experts of that issue (Riles 2000, 2002). For Riles, the phrase "human rights" is a historical object, a hybrid of political agenda and social movement. "Human rights" is an example of what Star and Greisemer (1989) call a "boundary object," an object of knowledge that is immutable and mobile, legible across disciplines and polities. "Anti-trafficking" is a similar sort of hybrid, simultaneously a phrase, a movement, and an agenda. "Anti-trafficking" is a mobile, boundary-crossing object, wielded by politicians, non-profit leaders, survivors, and technocrats alike. The mobility of the term leads us to focus on the spaces in which it has currency; as Riles suggests, focusing on "matters of 'form' in institutional practices" (2002: 291).

Our initial fieldwork suggests that anti-trafficking is taking the form of a counternetwork to the sex trafficking it seeks to address. The production of the network form also produces "anti-traffickers" as "knowledge professionals" committed to representing "the issue" and simultaneously upholding their status within the network. Anti-trafficking can be seen as both a project and as a representation: as a project, its actors must repeat the mantra of "anti-trafficking" in various political spaces; as a representation, "anti-trafficking" is more than phrasing, but a functional term to be "deployed" for action. Through language and normative judgment, antitrafficking actors produce their own network-a matrix of actors who are simultaneously enrolled and mobilized through their commitment to producing and distribution of information about the issue of anti-trafficking and at philosophical odds with one another based on moral, strategic, and tactical differences. "Antitrafficking," in its moral, activist, legal, and data-driven constitutions, can be seen as an emergent network parallel to the trafficking that it seeks to address.

Voicing varying definitions and understandings of trafficking within, around, and outside of the law, anti-trafficking actors place themselves at various nodes of the network relative to one another as well as funding agencies, law enforcement officials, health advocates, and interdisciplinary scholars. This complex network of actors and commitments gives "anti-trafficking" purchase as a term, an action, and an activist movement (albeit a somewhat fractured one). Riles suggests that this activist network phenomenon creates a "virtual sociality of rights" (2002: 286), in which anti-trafficking is simultaneously an activist strategy as well as a political viewpoint. Riles' article describes the discursive production and networked nature of the phrase "women's rights as human rights," which required the particular epistemic congregation of activists and academics at specific historic moments and places such as the Beijing Conference on Women. Riles labels these actors "knowledge professionals." Anti-trafficking is undergoing a similar moment, where academic researchers and activists at the anti-trafficking roundtables of conferences and meetings circulate data and documents in their search for definitions and ultimately with the simple shared goal of ending exploitation of certain persons. 
A striking example of relationality in the anti-trafficking network is the mobilization of actors necessary to advocate for the closure of Craigslist's sexual services site. Many non-governmental and government-affiliated organizations were interested in the possibility of this site's closure, dictated by a carceral approach to sex work in general. The closure movement gained momentum when one state's youth advocacy agency contracted a professional research group to conduct a study of Craigslist usage and the dynamics of demand in that state (Schapiro Group 2010). The use of networked contacts, the production of data, and the circulation of research documents is what we mean by "relationality" in the counter-network.

Going forward, we will continue to explore the ways in which anti-traffickers produce networks for themselves, as they argue for limits to classified and social media websites. At the time of this writing, debates around websites such as Backpage and myRedBook continue to emerge among anti-trafficking experts concerned with child sexual exploitation. Ongoing research questions for our project include: How do anti-trafficking advocates define technology, and in what ways are these definitions technologically deterministic? For example, how do certain discourses conflate classifieds websites with social media websites, and in so doing ascribe agency to media technologies as "drivers" of sex trafficking? How do antitraffickers use their discourses around technology to locate themselves within the larger anti-trafficking network?

The director of the human trafficking legal clinic notes that the predominant sex trafficking narrative in the United States is heavily raced and classed, directing media attention toward outlier cases of white, middle-class women who have potentially been trafficked. She comments wryly, "We have this view of sex trafficking...that those aren't the types of girls who would do sex work. They got tricked." In her view, the spinning of such narratives creates a clear distinction between sexual exploitation and sex work along racial and economic lines-that "those girls" would never voluntarily engage in sex work. This narrative not only erases the circumstances and realities of sex work, which includes people of multiple racial and economic backgrounds as well as sexualities and nationalities; it also denies agency and dignity to those doing sex work itself.

At a meeting we attended, a group of anti-trafficking organizations were asked how many sexually exploited children were under the control of a pimp. Representatives from two different organizations responded with radically opposing answers. A representative from an organization that works with survivors identified by law enforcement argued that most teenagers are pimp controlled, while a representative from an organization that primarily works with homeless youth engaged in "survival sex" argued that most commercial sexual exploitation of minors never involved a pimp. These two organizations, working with very different clientele saw the ecosystem in radically different ways. These expert advocates embody network relationality in their comprehension of similar information: "Persons interpret the acts of already existing social entities already related to themselves through their counter-interpretations" (1999: 245). Seeing anti-trafficking as a network form highlights, the "aesthetics of relationality" (Strathern 1995) as anti-trafficking actors perform their roles as well as their relationships. The issue 
at stake is not simply how these actors define the problem, but how their scoping shapes public discourse, interventions, and advocacy.

A researcher with an advocacy organization mused, "I think a lot of times, advocates on this issue just get stuck. I've literally been in meetings that have span over the course of multiple years where people are still trying to have the debate over what they want to call this problem. Who cares? ... Our goal is to find things that we can do, not to spend too much time debating what should be done because also coordination within the advocacy community is often a latent effect. You get coordination after someone gets a toe hold and you're able to make progress and then people will jump onboard because they are guided by their heart, by their mind, by the best evidence they have available to them at that time that this is a good way to go."

In providing this description, this researcher describes the efficacy of the antitrafficking network in perpetuating the network itself and yet continuing to situate actors as distinct, separable nodes, parallel to one another-supposedly working toward the same goal and yet always ideologically apart. There is an acquired technique or craft of rights discourse and anti-trafficking discourse: one cannot simply walk into a room of anti-trafficking activists and participate at the level of equal understanding to "get things done." Perhaps, because there are so many moral valences to trafficking (e.g., the age of sexual consent, the notion that sex work is labor, the politics of rescue, and the repatriation of trafficked migrants, to name a few), there are so few moments of emphatic nods in the room. Yet, even in order to disagree, participants "must share a register of contention that renders the conflict explicit to oneself and others" (Riles 2002: 298). The University of Colorado's clinic on human trafficking has even launched a "taxonomy project" aiming to trace the etymologies of human trafficking terms and assemble the trafficking lexicon, as it were. Anti-trafficking discourse is speech performance, and those in the network must remain articulate.

As a network of actors organized around a complex issue with many tangled facets, anti-trafficking advocates often seek to create clear boundaries and distinctions in order to position themselves-and their rhetoric-as central. In doing so, they construct a discursive network whose power rests on the ability to generate attention to the seriousness of the issue in order to secure resources.

\section{Technology as destabilizer}

Technology has reconfigured many aspects of sex trafficking (Latonero 2011; Boyd et al. 2011), altering the ways in which connections are made between exploiters, purchasers, and victims and changing the ways in which information flows regarding how to engage in criminal conduct. These reconfigurations, including the growth of social media usage alongside earlier mobile phone use, are documented in detail in a framework developed by the authors of this essay in December 2011 (Boyd et al. 2011). Law enforcement is using technology traces to identify perpetrators and that companies are doing data mining to identify illicit transactions. By creating new mechanisms to share information and connect, technology has the 
potential to increase exploitative transactions, but it also has the potential to create new opportunities to intervene. Meanwhile, some anti-trafficking advocates are using these same technologies to educate and spread anti-trafficking messages, coordinate campaigns, and fundraise. Yet, as is often the case in technology being deployed in civic networks, advocates are often less tech savvy than their illicit counterparts. In their assessment of local law enforcement attempts at citizen engagement, Foot and Vanek (2012) describe both the benefits of civic participation and the hazards of "Suspicious Activity Reporting," or community reporting and neighborhood self-policing on anti-trafficking advocacy work.

Many of the experts we spoke with were overwhelmed with anxieties over a seemingly technologically enhanced network of traffickers. Their concerns were temporally marked, distinguishing between a "before" period wherein exploiters relied upon (mobile) phones and personal networks, and a "now" period of not only those technologies but social media as well. They suggested that the use of Internet forums, chat, and classified sites fosters a connectivity and speed of connection among potential exploiters that gives the network of traffickers heightened confluence. A director of a legal clinic expresses her concern when she said, "My gut says that people that 30 years ago might not have committed to the act [of buying sex from an adolescent], now go through with it." Castells describes material-political configurations like this as the "network enterprise," a new form of economic organization made possible with increased connectivity and flexibility of informational production (2000: 10). These shifts are destabilizing, challenging advocates' efforts to understand networked trafficking and intervene in a productive way.

Much tactical disagreements stemmed from uncertainties regarding the efficacy of particular moves. While advocates universally agreed that prosecuting child victims did little to address the commercial sexual exploitation of children, they did not agree over the implications of shutting down websites or the role of technology in helping or hindering anti-trafficking efforts. The numerous unknowns meant that advocates often went on their gut instinct, but little effort was created to assess the efficacy of these strategies.

Faced with the uncertainty that comes from not knowing how to best proceed, many advocates simply want the technology to go away. A blanketed push for website elimination highlights the technologically deterministic viewpoint of these actors, who require the erasure of technology in order to restore a comprehension of trafficking within their frame of reference. Yet, while some advocates celebrated the closure of Craigslist, others - such as the one quoted at the opening of this essayexpressed concern over the efficacy. Other advocates noted the "hydra head" nature of closing sexual classified websites; as the director of a non-profit explained, "closing [the classified sites] would send a message, but new ones would pop up." While the advocates we interviewed all raised concerns about the ways in which technology is implicated in trafficking, they disagreed on what tactical measures should be taken to address technology.

Yet, for all of their uncertainty over the role of technology in anti-trafficking, many advocacy organizations recognized technology as a powerful role in everyday people's lives. The director of an anti-exploitation organization told us that 
according to the trafficking survivors she has been working with, "the Internet has made it so much easier for perpetrators to link up." She noted that "the same things that make it easier for us," as non-traffickers, to connect with one another enable increased speed and efficacy of communication between potential traffickers and exploiters. While she is referring to the use of technology for sociable purposes, many anti-trafficking organizations have also embraced technology to build powerful networks of allies, advocates, and donors.

As Castells has argued, the ability to build networks and influence how information flows across them is one of the most influential forms of power in a networked society (2009: 45). By altering the landscape and reconfiguring how information flows, new technologies destabilize existing infrastructures of power. What follows is a scramble for power. Many anti-trafficking advocates responded to the destabilization brought on by technology by lamenting what they lost rather than seeing new opportunities to intervene. A few recognized the potential for leveraging technology to intervene in new ways. Yet, in an ironic twist, by using technology to build their own powerful networks, the anti-trafficking movement may have benefited as much, if not more, than the traffickers they seek to challenge.

Acknowledgments This research is part of the Human Trafficking Project at Microsoft Research, supported by the Social Media Collective at Microsoft Research, Microsoft Research Connections, and the Microsoft Digital Crimes Unit. We are grateful for tremendous intellectual guidance and support from Heather Casteel (University of Massachusetts at Amherst), Rane Johnson-Stempson (Microsoft Research), Samantha Doerr (Microsoft), Sue Hotelling (Microsoft), Mark Latonero (University of Southern California), and Jennifer Musto (Rice University).

Open Access This article is distributed under the terms of the Creative Commons Attribution License which permits any use, distribution, and reproduction in any medium, provided the original author(s) and the source are credited.

\section{References}

The AIM Group. 2012. Prostitution-ad revenue still falls short of past Craigslist totals. The AIM Group. http://aimgroup.com/2012/08/24/prostitution-ad-revenue-still-falls-short-of-past-craigslist-totals. Accessed 10 September 2012.

Albanesius, Chloe. 2010. Craigslist confirms permanent shutdown of adult services. PC Magazine. http://www.pcmag.com/article2/0,2817,2369227,00.asp. Accessed 10 September 2012.

Anderson, B., and Julia O'Connell Davidson. 2003. Is trafficking in human beings demand driven? a multi-country pilot study. Geneva: International Office for Migration.

Andrijasevic, Rutvica. 2007. Beautiful dead bodies: Gender, migration, and representation in antitrafficking campaigns. Feminist Review 86: 24-44.

Connecticut Attorney General's Office. 2009. Attorney General seeks stronger measures-Including financial penalties and incentives-To fight prostitution and pornography on Craigslist [Press Release]. Retrieved from http://www.ct.gov/ag/cwp/view.asp?Q=438868\&A=3673. Accessed 10 September 2012.

Augustin, Laura M. 2007. Sex at the margins: Migration, labour markets and the rescue industry. London: Zed Books.

Bernstein, Elizabeth. 2007. The sexual politics of the 'New Abolitionism'. differences. Journal of Feminist Cultural Studies 18(3): 128-151. 
Boothroyd, Horace. 2012. Sexual Slavery Website Funded by Goldman Sachs with 16\% Share. The Daily Kos. http://www.dailykos.com/story/2012/04/01/1079647/-Sexual-Slavery-Website-Funded-by-Gold man-Sachs-with-16-Share. Accessed 10 September 2012.

Boyd, Danah, Heather Casteel, Mitali Thakor, and Rane S. Johnson. 2011. Human trafficking and technology: A framework for understanding the role of technology in the commercial exploitation of children in the US. Microsoft Research. http://research.microsoft.com/en-us/collaboration/ focus/education/htframework-2011.pdf. Accessed 10 September 2012.

Castells, Manuel. 2000. Materials for an exploratory theory of the network society. The British Journal of Sociology 51(1): 5-24.

Castells, Manuel. 2009. Communication power. Oxford: Oxford University Press.

Chapkis, Wendy. 1997. Live sex acts: Women performing erotic labor. New York: Routledge.

Charlesworth, Hilary, Christine Chinkin, and Shelley Wright. 1991. Feminist approaches to international law. American Journal of International Law 85: 613-645.

CNN Wire Staff. Attorneys general call for Craigslist to get rid of adult services ads. 2010. CNN. http://articles.cnn.com/2010-08-25/justice/craigslist.adult.content_1_craigslist-ceo-jim-buckmasterjulissa-brisman-adult-services-ads?_s=PM:CRIME. Accessed 10 September 2012.

Collins, Harry, and Robert Evans. 2002. The third wave of science studies: Studies of expertise and experience. Social Studies of Science 32(2): 235-296.

Desyllas, Moshoula Capous. 2007. A critique of the global trafficking discourse and US. policy. Journal of Sociology and Social Welfare 34(4): 57-79.

Ditmore, Melissa. 2005. Trafficking in lives: How ideology shapes policy. In Trafficking and prostitution reconsidered: New perspectives on migration, sex work and human rights, ed. Kamala Kempadoo. Boulder: Paradigm Publishers.

Doezema, Jo. 1998. Forced to choose: Beyond the voluntary v. forced prostitution dichotomy. In Global sex workers: Rights, resistance and redefinition, ed. Kamala Kempadoo and Jo Doezema. New York: Routledge.

Doezema, Jo. 2010. Sex slaves and discourse masters: The social construction of trafficking. London: Zed Books.

Dworkin, Andrea. 1993. Prostitution and male supremacy. Michigan Journal of Gender and Law 1: 1-12.

Epstein, Steven. 2000. Democracy, Expertise, and AIDS Activism. In Science, Technology and Democracy, ed. Daniel Lee Kleinman. Albany, NY: SUNY Press.

Foot, Kirsten, and John Vanek. 2012. Toward constructive engagement between local law enforcement and mobilization and advocacy nongovernmental organizations about human trafficking: Recommendations for law enforcement executives. Law Enforcement Executive Forum 12(1): 1-11.

Forsythe, Diana. 1999. Ethics and politics of studying up in technoscience. Anthropology of Work Review 20(1): 6-11.

Gerhart, Ann. 2010. Sex-trafficking opponents fight Craigslist's 'adult services' ads. The Washington Post. http://www.washingtonpost.com/wp-dyn/content/article/2010/08/06/AR2010080606376.html. Accessed 10 September 2012.

Gruenwald, Juliana. 2010. Groups urge craigslist to eliminate foreign adult services ads. National Journal. http://techdailydose.nationaljournal.com/2010/09/groups-urge-craigslist-to-elim.php. Accessed 10 September 2012.

Hinman, Katie and Melia Patria. 2012. Girls sold for sex online, backpage defends decision to keep ads up. ABC News. http://abcnews.go.com/US/girls-sold-sex-online-backpage-defends-decision-ads/story? $\mathrm{id}=16193220$. Accessed 10 September 2012.

Kara, Siddharth. 2009. Sex trafficking: Inside the business of modern slavery. New York: Columbia University Press.

Kempadoo, Kamala, and Doezema Jo. 1998. Global sex workers: Rights, Resistance, and Redefinition. New York: Psychology Press.

Latonero, Mark. 2011. Human trafficking online: The role of social networking sites and online classifieds. University of Southern California. Center on Communication Leadership and Policy. https://technologyandtrafficking.usc.edu/files/2011/09/HumanTrafficking_FINAL.pdf. Accessed 10 September 2012.

MacKinnon, Catharine. 1993. Prostitution and civil rights. Michigan Journal of Gender and Law 1: $13-31$.

Mahmood, Sabah. 2004. The politics of piety: The islamic revival and the feminist subject. Princeton: Princeton University Press. 
Musto, Jennifer Lynne. 2009. What's in a name? Conflations and contradictions in contemporary US. discourses of human trafficking. Women's Studies International Forum 32: 281-287.

Nader, Laura. 1972. Up the Anthropologist-Perspectives gained from studying up. In Dell H, ed. Reinventing Anthropology, 284-311. Hymes: New York, Pantheon Books.

National association of human trafficking advocates. 2012. Letter to national association of attorneys general. Tennessee state. office of congresswoman Marsha Blackburn http://blackburn.house.gov/ uploadedfiles/letter_from_anti-trafficking_organizations.pdf. Accessed 10 September 2012.

Pinto, Nick. 2011. Women's funding network sex trafficking study is junk science. The Village Voice. http://www.villagevoice.com/2011-03-23/news/women-s-funding-network-sex-trafficking-study-isjunk-science/. Accessed 10 September 2012.

Riles, Annelise. 2000. The network inside out. Ann Arbor: University of Michigan Press.

Riles, Annelise. 2002. Rights inside out: The case of the women's human rights campaign. Leiden Journal of International Law 15(2): 285-305.

Saar, Malika Saada. 2012. The internet, Backpage, Child Trafficking, Congress—and Our Responsibility to Vulnerable Children. Congressional Victims' Rights Caucus. http://poe.house.gov/index. php?option=com_content\&view=article\&id=8740:huffington-post-blog-the-internet-backpage-childtrafficking-congress-and-our-responsibility-to-vulnerable-children\&catid=130: articles \&Itemid= 134\&layout=default\&date=2012-10-01. Accessed 10 September 2012.

Saletan, William. 2010. Pimp mobile. Slate. http://www.slate.com/articles/news_and_politics/frame_ game/2010/09/pimp_mobile.html. Accessed 10 September 2012.

Sarnoff, Conchita. 2012. Backpage not complying with requests to help stop sex trafficking. The Huffington

Post. http://www.huffingtonpost.com/conchita-s-sarnoff/backpage-not-complying-wi_1_b_1398465.html. Accessed 10 September 2012.

The Schapiro Group. 2011. Men Who buy sex with adolescent girls: A scientific research study. Women's Funding Network. http://www.womensfundingnetwork.org/sites/wfnet.org/files/AFNAP/TheSchapiro GroupGeorgiaDemandStudy.pdf. Accessed 1 May 2012.

Soderlund, Gretchen. 2005. Running from the rescuers: New US. crusades against sex trafficking and the rhetoric of abolition. NWSA Journal 17(3): 64-87.

Strathern, Marilyn. 1995. The relation: issues in complexity and scale. Prickly Pear Pamphlet 6. Cambridge: Prickly Pear Press.

Strathern, Marilyn. 1999. Property, substance, and effect: Anthropological essays on persons and things. New Brunswick: The Athlone Press.

Weitzer, Ronald. 2007. The social construction of sex trafficking: Ideology and institutionalization of a moral crusade. Politics and Society 35(3): 447-475. 